
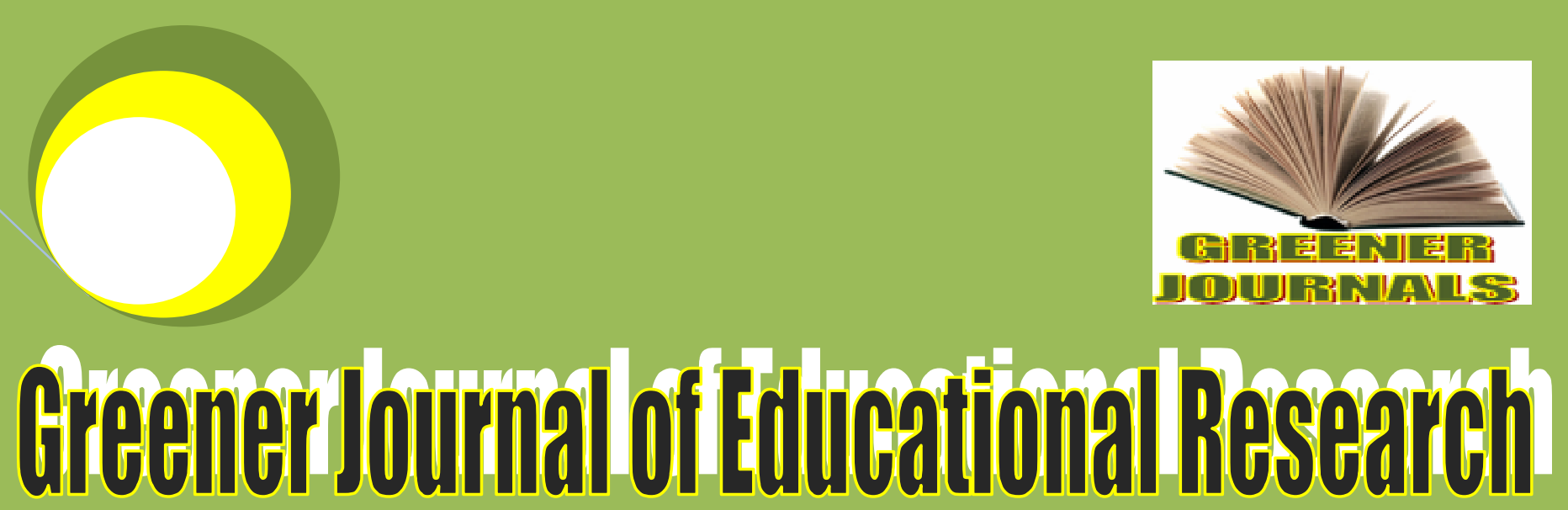

ISSN: 2276-7789 ICV: 6.05

Submitted:16/05/2016

Accepted: 27/05/2016

Published: 31/05/2016

DOI: http://doi.org/10.15580/GJER.2016.3.051616087

Influence of Employment Factors on Stress among Public Secondary School Teachers in Kenya. A

Case Study of Kakamega North Sub-county

By

Olive Taabu Baraza

Enose M.W. Simatwa 


\title{
Influence of Employment Factors on Stress among Public Secondary School Teachers in Kenya. A Case Study of Kakamega North Sub-county
}

\section{Olive Taabu Baraza and Enose M.W. Simatwa*}

\author{
Department of Educational Management and Foundations, Maseno University.
}

*Corresponding Author’s Email: simatwae@ yahoo .com

\begin{abstract}
Stress is a complex concept that for many years has not been taken seriously and hence lacks adequate definition. To some scholars stress is any external stimulus that causes wear and tear on one's psychological or physical well-being. Other scholars define it as tension, pressure, anxiety or worry resulting from one's life events. These definitions imply that stress is a condition arising from the interaction of people and their jobs, characterized by changes within people that force them to deviate from normal functioning. Under normal conditions, our bodies and minds are in a state of equilibrium. As a result of occurrences on and off the job however, our equilibrium may be disrupted. In attempting to recover from this imbalance, we function differently and sometimes generate a fight-or-flight chemical reaction. A person under severe or prolonged stress cannot function as effectively as a person leading a more balanced life. This does not imply that stress is all negative, some amount of stress is necessary to accomplish anything meaningful because certain amount of stress adds zest to life. The link between perceived work-related stress and impaired functioning on the job is well-documented, demonstrating the classic inverted U-shaped relationship between stress and performance. That is, employees who experience a moderate degree of job stress perform their jobs most efficiently, while those who experience either low or high work-related stress show reduced work efficiency. Students in Kakamega North Sub county's performance was below average from 2009 to 2013. The mean scores of Kenya Certificate of Secondary examinations remained below 4.3compared to neighbouring sub counties that had recorded higher mean scores of 5.1 and above for the same period. That is, Mumias Sub -county had 5.80, Kakamega Sub-county had 5.40, Kakamega East Sub County had 5.20 and Matete Sub-county had 4.90. Stress related cases were also on the increase in the sub county with cases of transfer requests rising from 14 in 2009 to 400 in 2013. The purpose of this study was therefore to establish employment factors that influence stress among secondary school teachers in public secondary schools in Kakamega North Sub-county. The study adopted descriptive survey and correlational research designs. The study population consisted of $\mathbf{4 5}$ principals, 133 teachers and one Teachers Service Commission County Director. Quantitative data was collected using questionnaires and document analysis guide while qualitative data was collected using interview schedules. Data was collected by use of questionnaires, interview schedules, and document analysis guide. The study established that employment factors accounted for $11.8 \%$ of the variation in teachers' stress. This means that $88.2 \%$ of the variation was due to other factors that were not subject of this study. Since the employment factor that had the highest impact on teachers' stress was government decisions on teachers strike, this study recommended that industrial disputes involving national strike should be dealt with strictly in accordance with the legislation that govern labour relations. The wage bill for teachers should also be regularly reviewed and collective bargaining agreements adhered to by both the teachers' trade union and the government.
\end{abstract}

Key Words: Influence, Employment Factors, Stress, Public Secondary School, Teachers, Kakamega North Sub-county, Kenya.

\section{INTRODUCTION}

Globalization of education has led to an increase in the growth of educational institutions all over the world and the education scene in Kenya is not an exception especially with the current scenario of trying to achieve Vision 2030. According to Aikman and Unterhalter (2005), globally, educating a nation remains the most vital strategy for the development of the society throughout the developing world. In essence, teachers are looked upon as the key stakeholders in the teaching profession. Teachers like other workers in different professions do experience stress. According to Sprenger (2011) in a study on stress and coping behaviors among primary school teachers in North Carolina, one hundred percent of teachers interviewed for this study reported that the teaching profession is stressful, with $72 \%$ describing the profession as extremely or very stressful. Decenzo and Robbins (20 06 ) indicate 
that stress is a dynamic condition in which an individual is confronted with an opportunity, constraint, or demand, related to what he or she desires and for which the outcome is perceived to be both uncertain and important. Stress can manifest itself in either a positive or negative way. It is positive when a situation offers an opportunity for one to gain something, but when constraints of demands are placed on us then it is negative. According to Bratton and Gold (1999), stress is now part of the regular vocabulary of managers and employees. While some stress is normal to life, if stress is repeated or prolonged, it causes psychological discomfort. Stress has an impact on productivity. According to Subbulaxmi (2002), stress can have various effects on the individual as well as on the organization. Clearly, not only the individual suffers but the organization may also be affected by absenteeism, work related accidents, turnover and impaired decision making. People get sick from stress at work and the cost associated with stress is high, hence significant to the employer. Stress is associated with constraints and demands. Constraints prevent the person from doing things he or she desires. Management may not be concerned when employees experience low to moderate level of stress. Such levels may lead to higher employee performance. But high levels of stress or even low levels sustained over a long period of time, can lead to reduced employee performance and thus require action by management.

According to Beckley (2011) in his study on the well being of New Zealand teachers, the relationship between health, stress, job demands and teacher efficacy, over $39 \%$ of teachers considered teaching to be either very stressful or extremely stressful. This means that most teachers experience stress. The study used a crosssectional research design. The study used a 10 item perceived stress scale to determine the stress levels. Correlation was done to determine the relationship between health, stress, job demands and teacher efficacy. However, this stress scale is not exhaustive as it does not cover all the areas within the teaching environment. The study sample size was 131 teachers randomly selected across New Zealand schools. The study population has not been indicated and so we cannot generalize that the sample size was a representative of the study population. The study did not also indicate instruments of data collection; it is therefore not easy to assess the suitability of the instruments used.

Siddiqui (2012), in a study on occupational stress in teachers: a comparative study of public and private schools in Hyderabad city in India found out that it was a fact that female teachers working in public schools as compared to working in private schools lack resources like advanced technologies. Somehow, this could be considered a contributing factor in their stress level. The Urdu version of the Occupational Stress Scale developed by Sohailand Khanum (2000) was used by Siddiqui (2012) to explore the difference between the level of occupational stress experienced by public and private schools. Siddiqui (2012) had a sample size of 90 teachers from public schools and 90 teachers from private schools. However, the study did not indicate the total population of the study to be able to assess the appropriateness of the sample size. The study did not also indicate the research design. It is therefore difficult to authenticate the results of the study.

Anbu (2015) in his study on professional stress of higher secondary school teachers, the female higher secondary school teachers have more stress than the male higher secondary school teachers. The reason is that female teachers apart from guiding the terminal stage school students, they have to look after their family members, they are not able to allocate equal weight to working as well as to the family, and hence this results in enhanced stress levels. Married higher secondary school teachers have more stress than the unmarried higher secondary school teachers because married teachers do shoulder more responsibilities than the unmarried in terms of school work as well as in the family and society, hence they are in the position of satisfying all the dimensions which result in higher level of stress. Higher secondary school teachers working in government schools have more stress than those working in private higher secondary schools because government teachers have to fulfill the work and the task given to them from time to time from the administration as well as from the government departments, hence they are more responsible to the government officials than the private higher secondary school teachers, hence a higher level of stress was evident in the government school higher secondary school teachers. Survey method was used for this study. The sample consisted of 200 post graduate teachers working in government and private higher secondary schools in and around Nagercoil region. The occupational Stress Inventory used was developed by Dr. Joseph and Dr. Dharmangadan. The five point scale consisted of 37 test items, which included positive and negative statements.

In America, Dessler (2008) indicates that external factors can lead to job stress. These include work schedule, pace of work, job security, route to and from work, and the number and the nature of customers or clients. According to him, job stress has serious consequences for both the employer and employee. The human response consequences include anxiety, depressions, anger and various physical consequences such as headaches and accidents. For the organization, it includes reductions in the quantity of performance, and increased absenteeism and turnover. According to Sprenger (2011) in a study on stress and coping behaviors among primary school teachers in North Carolina, unrealistic expectations set forth by school officials and parents are the most frequent sources of stress followed by excessive paperwork, and school administration. A mixed method research design was used to assess stress and coping behaviors among primary school teachers. This study used appropriate research design as 
one method could not provide answers to all the research questions. However, the study questionnaire was not exhaustive; it did not cover all the areas that surround a teacher, the study also focused on primary teachers.

According to Antoniou, Polychroni, and Vlachakis, (2006) in their study on gender and age differences in occupational stress and professional burnout between primary and high-school teachers in Greece, found out that occupational stress leads to unwanted feelings and behaviors such as job dissatisfaction, lower motivation, low employee morale, less organizational commitment, lowered overall quality of work life, absenteeism, turnover, intention to leave the job, lower productivity, decreased quantity and quality of work, inability to make sound decisions, occupational burnout, alienation, and increased smoking and drug intake.

According to Tuck, Eleanor, Manthei, Adair, Adair and Moore (1999) in their study on sources of occupational stress in New Zealand, primary teachers reported moderate levels of stress and job satisfaction. The study found out that disruptive students, inadequate remuneration, task overload, lack of respect for teachers, inadequate resources and administrative support were sources of mild to moderate stress. The study used 30 item likert type scale. However, the study did not address the percentage contributed by these factors on teachers' stress levels, the study also did not address factors influencing stress among teachers in secondary schools in Kakamega North sub-county, a knowledge gap that the current study sought to fill.

Younghusband (2005) in a study on high school teachers' perceptions of their working environment in Newfoundland found out that the major stressors have remained much the same: heavy workloads, time pressures, inadequate administrative support, students misbehaviour, inadequate resources, restructuring and the reality of constant change, inclusive classes, and a host of other concerns. According to him, there are a multitude of international studies which indicate that teacher stress is increasing and that stress is a threat to the quality of personal and family life as well as physical and psychological well- being, which indicate that teacher stress is increasing. This study observed that a multitude of international studies indicate that teachers' stress is increasing. However the study did not indicate when the multitude international studies were done and where they were carried out. This study did not also indicate the research design that was used in the study and therefore it is difficult to authenticate the results. The study did not compute the correlation on the factors to determine whether the factors were significant on stress among teachers, a knowledge gap that the current study sought to fill.

Areekkuzhiyil (2014) in his study on factors influencing the organizational stress among teachers working in the higher education sector in Kerala: An empirical analysis identified nine factors which determine the organizational stress of teachers working in the higher education sector in the state. These factors, which significantly influence the organizational stress of teachers in the higher education sector, were interpersonal relationship in the organization, professional and competence development, recognition in the organization, work environment, autonomy in work, work family interaction, role conflict, job security and remuneration, and non-academic works. The study sample size was 200 respondents. However, the research design that was used was not indicated, the study population was also not indicated; therefore the findings cannot be authenticated. These nine factors were identified as responsible for organizational stress of teachers working in the higher education sector in the state, however, their actual contribution to stress among teachers in secondary schools is not known, a knowledge gap that the current study sought to fill.

In Kenya, on causes of burnout among secondary school teachers: a case of Bungoma North District, Kenya, Sichambo, Maragia and Simiyu (2012) revealed that apart from the normal classroom teaching, teachers had a number of remedial lessons to attend to, larger classes to handle, a lot of paper work and some had to stay in their work stations other than their normal school timings in order to complete various tasks. All these factors were contributing to burnout among teachers which were badly impacting their performance. This study adopted a survey research design. Further study on socio-demographic factors and causes of job stress of sports personnel in Kenyan universities, Rintaugu (2013) found out that causes of stress among sports personnel were: decreased job mobility, large number of university students who do not take part in sports, lack of relationship between successful sports performance and promotion, and inadequate personnel. The least causes of stress were poor relationship with fellow sports administrators, working under pressure, pressure of university administrators to produce results, supervision of sport programs are low and lack of career development while administering sports. The design of the study was descriptive survey research design. This design was appropriate to the study. The study used questionnaires to collect the data. The study could have used other methods such as focus group discussions and interviews to collect data. This study focused on causes of stress among sports personnel in Kenyan universities. However, it did not address factors causing stress among secondary teachers, a knowledge gap that the current study sought to fill.

Studies reviewed by Beckley (2011) in New Zealand, Tuck, Hawe, Manthei Adair and Moore (1999) in New Zealand and Sichambo, Maragis and Simiyu (2012) have shown that the following factors have contributed to stress among teachers: a lot of paper work, larger classes, role overload and unrealistic deadlines. However, these studies did not deal with the influence of school factors on stress among secondary teachers in Kakamega North sub-county, the knowledge gap the study sought to fill. 
In a study on an empirical study of stressors that impinge on teachers in secondary schools in Swaziland, Okeke (2013), found out that the major stressors included the lack of power and influence, threat of job losses, performance related incentives, poor pay, lack of accommodation, badly planned changes, temporary contracts, and shortage of teachers. This study employed the descriptive correlation research design to determine the relationship between stressors and teachers stress among secondary school teachers. This research design was very appropriate in finding the relationship between teachers stress and the teachers working environment.

Sulaiman and Akinsanya (2014) focused on stress and instructors' efficiency in Ogun State Universities: Implications for Nigerian educational policy compared teachers in public and private universities, which revealed that teachers from both universities were working under stress, albeit public universities teachers were more prone to stress than their counterparts in private universities. The study showed that teachers in public universities did not enjoy a conducive working environment when compared with their counterparts. This study did not indicate the research design that was used in the study and so it is difficult to authenticate the results. Teachers in private and public universities should not be compared as they are different environments and under different managements. However, this study was limited to influence of employment factors on teachers in public and private universities. It did not address the influence of employment factors on stress among teachers in secondary schools, a knowledge gap this study sought to fill. This study showed that employment factors such as remuneration was a stressor in public universities however, its actual contribution on stress among teachers is not known.

Wangai (2012), in her study on factors affecting job satisfaction among secondary school teachers of Mwatate district, Kenya found out that salary level was ranked as the most important factor towards job satisfaction and poor pay as the most dissatisfying job factor. This study used descriptive survey research design. The target population was 21 secondary schools and 217 secondary school teachers. 23 teachers responded out of a total population of 217 forming. This made a sample size of $10.5 \%$. This sample size is too small to represent the entire population. The study used questionnaires to collect data. The study could have incorporated other methods such as interviews and focus group discussions to get a variety of responses. Studies reviewed on stressors in teaching by Okeke and Dalamin (2013) in Swaziland, Sulaiman and Akinsanya (2014) in Nigeria, Wangai (2012) in Kenya using descriptive survey research design have found out that poor pay and job security contributes to stress among teachers.

In Malaysia, in a study on occupational stress and turnover intentions among school teachers in Negeri Sembilan, Malaysia, Salahudin, Abdullah and Hitam (nd), found out that female teachers are more stressful in their job compared to their male counterparts. This seems to suggest that female teachers in the present study observed higher stress due to their dual commitment to their job and their family. Another finding is that occupational stress would differ significantly according to the respondents' race, age, income and educational level. The Indian teachers tend to demonstrate higher stress levels which could be related to their minimum association in their workplace when compared to other races due to the fact that they are the minority group in the schools. The younger teachers demonstrate lower level of stress compared to older teachers.

A research on relationship of stress and job satisfaction: a comparative study of male and female of dual career teacher couples of India by TJjpti, Avantika, Prabha (2007) indicate that female members face more stress than the male members. Both genders with high work-family conflict and work-role stress have lower levels of job satisfaction than those facing lower family conflict and work-role stress. Females facing high family roles stress experience higher job satisfaction than those facing low family role stress. Already prepared and standardized psychometric measures: Organizational Role Stress Scale (ORS; Pareek, 1983), Satisfaction-Dissatisfaction (S-D) Employee's Inventory (Pestonjee, 1973), Family Role Stressors Questionnaire (Singh \& Singh, 1996), and WorkFamily Conflict Scale (Singh \& Singh, 1996) to measure the relationship of stress and job Satisfaction. The measurement tools were appropriate, however the study did not indicate the research design used to measure the relationship between job stress and job satisfaction.

Tasleema, Malik, Ahmad, (2013) in their study on social and family role stress among primary school teachers of district Budgam, private female primary school teachers were found to have more stress as compared to Government female primary school teachers of District Budgam found out that the main reason is that private females feel insecurity in terms of safety, job, pressure from home and society. Tasleema, Malik, Ahmad, (2013) focused on stress among primary teachers. They used The Social and Family Role Stress Scale by S. Sultan Akhter and Priti Vadra to analyze data. The current study will use rating scales to analyze the data. This study focused on social and family role stress among female primary teachers. However, it did not address the influence of familial factors on stress among teachers in public secondary schools in Kakamega north sub-county knowledge gap that the study sought to fill.

Kithokoo (2008), in his study on school factors affecting performance in Kenya Primary School Certificate in public primary schools in Yatta division lower Yatta District, Kitui county found out that a number of school factors were found to affect performance. The factors include; number of teachers, understaffing, availability of teaching and learning materials and enrolment level. This study focused on factors influencing performance in primary schools ; 
however, it did not address factors influencing performance in secondary schools. The study did not address the influence of stress among teachers on students' academic performance in secondary schools, a knowledge gap that the current study sought to fill.

According to Karihe, Namusonge and Iravo (2015) in their study on effects of working facilities stress factors on the performance of employees in public universities in Kenya; workers under stress cannot perform well. Their job satisfaction and motivation levels are decreased and they show unwanted behaviours like absenteeism, mistakes during work, drugs use and abuse and violence at work. Furthermore they have more health related physical and psychological complaints. The university employees' satisfaction level is also decreased in such a way that the university cannot offer quality education to the students. The resultant effect include complaints from parents and other stakeholders on the status of service delivery at the institutions, frequent strikes, dissatisfied employees and poor performance of the universities in general, and eventually the overall image of the educational institution gets damaged The research design used for the study was a cross- sectional evaluation survey. Cluster sampling technique was employed for the survey. The data collection tools used for the study were a questionnaire and interview schedules to obtain data from primary sources and a document review and analysis for secondary sources.

\section{Research Objective}

The research objective was: Determine the influence of employment factors on stress among public secondary school teachers in Kakamega North sub-county.

\section{SYNTHESIS OF LITERATURE UNEMPLOYMENT FACTORS THAT INFLUENCE STRESS AMONG PUBLIC SECONDARY SCHOOL TEACHERS}

In America, Shernoff, Mehta, Atkins, Torf and Spencer (2011) in a study on a qualitative study of the sources and impact of stress among urban teachers, one-half of the cases identified lack of resources, excessive workload, school-level disorganization, managing behavior problems, and accountability policies as significant sources of stress. This study focused on urban teachers however, the study did not address causes of stress among teachers in rural areas, a knowledge gap that the current study sought to fill.

Curtaz (1997) in her study on perceived causes of stress and burnout as reported by elementary teachers at an urban school, teachers spent many days and nights working toward keeping the school off the closure list. This included several meetings after school and sometimes late into the night, contacting and working with parents as well as getting the word out to the community. The teachers were under an immense amount of stress that was out of their immediate control. Furthermore, teachers interviewed indicated that they felt more stress with their jobs when there were problems with the administration. The study used a case study research design.

According to Kaur (2011) as quoted in Siddiqui (2012), teachers stress is the outcome of school management's disability to fulfill teacher's needs and demands. Further study by Syed, Alain and Muhammad (2012) in their study on impact of organizational role stressors on faculty stress and burnout in Pakistan found out that role ambiguity is one of the organizational role stressors having the biggest impact on two dimensions of stress and one dimension of burnout among the faculty. The other significant organizational role stressors include role stagnation, inter-role distance, self role distance, resource inadequacy, role conflict and role overload.

According to Santiago et al (2008) in his study on occupational stress in secondary school teachers: examining the role of students' disruptive behavior and or attitudes and the perceived difficulty in conflict management in Espania found out that the stress associated to students' disruptive behaviour and to the difficulties faced by teachers in managing conflict has a greater incidence on female teachers on second cycle teachers and on intermediate stages in the profession. Santiago et al (2008) used Inventory of Occupational Stressors of Secondary School Teachers (Inventario de Estresores Laboralespara Profesores de Secundaria -IELPS-; Otero López et al., 2006) to analyze data. The current study will use rating scales to analyse data. The study focused on the influence of students' disruptive behaviour on teachers stress. However, the study did not address other stressors in the school environment a knowledge gap that the current study sought to fill.

In a study on occupational stress on job satisfaction among teachers with particular reference to corporate, higher secondary school of Nepal: empirical study, Kayastha and Kayastha (2012) found out that occupational stress is associated with job satisfaction. Occupational stress was negatively associated with six job satisfaction facets. It was seen that a high level of occupational stress will reduce job satisfaction. Reducing occupational stress such as workload; conflict; unreasonable group and political pressures may lead to high satisfaction with regards to work, pay, co-workers, and supervision promotion and job in general. Questionnaires were used to collect data. This study did not indicate the research methodology that was used in the collection data. It is thus difficult to verify its authenticity. According to Torres, Lawver and Lambert (2009), in their study on job-related stress among secondary 
Agricultural education teachers: a comparison study in Missouri, concluded that, Agriculture teachers in Missouri and North Carolina are not in an overall state of stress compared with norm data. However, time related job tasks were found to be a source of stress among both teacher samples, and excessive paperwork was identified as the highest stressor. Low stress items among teachers fell into three broad job related categories best described as supervision, advancement, and inactivity. This study focused on job related stress Agriculture teachers only. Data was collected by using the job stress survey developed by Spielberger and Vagg (1999). The study used descriptive-survey research. This is a comparative study and so the researcher could have used correlational research design to correlate the two areas. This study focused on job-related stress among Agricultural education teachers. However, the study did not address job-related factors affecting teachers teaching other subjects, a knowledge gap that the current study sought to fill.

According to Tsai, Fung and Chow (2006) in Hong Kong in their study on sources and manifestations of stress in female kindergarten teachers, time management and work related stressors were more common sources of stress whereas feelings of fatigue and emotionally related symptoms are more common manifestations of stress. Assessment of data was done using teacher stress inventory. Tsai, Fung and Chow (2006) did not indicate the study population too. Itis difficult to establish whether the sample size was appropriate. The research methodology was also not indicated and therefore difficult to authenticate the results. The study was limited to female kindergarten teachers.

Ozturk (2011), in a study on public primary school teachers' perceptions of their working conditions and job stress: cases from Istanbul and Stockholm found out that for teachers working in Istanbul, the main reasons of job stress were paperwork, computer work, administrative duties; meetings with colleagues and parents, too many conferences; too much work, take work to home; less time; relations with students and their psychological and social well-being, and parents' demands from teachers; the least stressful elements were lunch time, parents' demands on their children, and parents' personal problems.

Zedan (2012) on stress and coping strategies among elementary school teachers in Israel found out that the ten greatest causes of stress for Israeli teachers are: overloaded classes, problems in pupil behaviour, disdain of pupils for class assignments, pupils without motivation, lack of teaching resources (teaching hours, teaching assistants), violence in school, inconvenient working conditions (schedule, work load, etc.), lack of public understanding of the burden placed upon the teacher, overloaded study program, integration of pupils with special needs. A sample size of 425 teachers was selected, what is unknown is whether 425 teachers was a representation of the total population. This study used structured questionnaires to collect data. Questionnaires alone cannot give you enough data, the study could have added other methods which include interviews and document analysis. This study focused on stress and coping strategies among elementary school teachers.

In a research on a qualitative study of workplace stress and coping in secondary teachers in Ireland Kerr, Breen, Delaney, Kelly, Miller (2011) showed great concern for their students, with some being prepared to ignore school guidelines in order to deal with their pupils' needs. Several, particularly stressful factors were identified, including the maintenance of boundaries (especially when dealing with students with personal problems), dealing with disruptive student behaviour, and the heavy workload.

Senthil, Mohan, Velmurugan (2013) in their study on causes of work stress of teachers in Engineering education in India, found out that significant association among gender, type of institution, location of the college, current working status and average number of working hours which causes stress. Questionnaires were used to collect data. This study focused on teachers in engineering education in colleges and universities. However, the study did not address factors causing stress among teachers teaching other subjects in secondary schools, a knowledge gap that the current study sought to fill.

In a study on prevalence of job stress among primary school teachers in South-west, Nigeria, Olaitan, Oyerinde, Obiyemi and Kayode (2010) revealed that the teachers' major sources of stress were colleagues, curriculum, marking, parents, pupils, school authority, society, supervision / teaching, teaching environment and wages. Jaiyeoba and Jibril (2008) on sources of occupational stress among secondary school administrators in Kano State, Nigeria showed that, administrative routine, work load, and conflicting demands and roles between work and family were the highest sources of stress. Further study by Adeniyi, Fakolade, Aremumand Tella, (2010), in their study on perceived causes of job stress among special educators in selected special and integrated schools in Nigeria found out that stress or burnout is caused by several factors as follows: lack of progress achieved on the part of the students and teachers, workload of the teachers, lack of help or assistance, in respect of numbers of special educators available and increase or over population of students especially in mainstream schools. When teachers see little or no progress in student learning, psychological trauma develops and eventually leads to stress. According to Hasting and Brown (2002) as quoted by Adeniyi, Fakolade, Aremu and Tella (2010) found out that, special teachers face high levels of anxiety as a result of their pupils' progress. physical environment and resources, workload and time pressure, changes in educational policies, students, parents, rewards, relations with colleagues and principals, role conflict, and school structure and management among others are sources of stress in schools. 
According to Maphalala (2014) in his study on the manifestation of occupational stress in the teaching profession: the unheeded voices of teachers in South Africa, teaching stressors which the teachers found stressful, in order of most to least stressful, were curriculum changes, work load pressures, job insecurity, poor relationship with colleagues, reward and recognition, learners discipline problems, poor rapport with management and role ambiguity. In a research on factors contributing to the causes of work related stress and its impact on performance of teachers in Nkayi District, Zimbabwe, Ncube and Tshabalala (2013), found out that the major causes of stress among the respondents were poor pay, work overload, bad school management role overload and large class sizes. A study on the extent and causes of stress in teachers in the George region by Olivier (2003) indicated that the stress levels of teachers in the George area are average, but teachers nevertheless expressed concern about teaching factors that cause them stress. In this regard, they mentioned inadequate salaries, lack of discipline in the school, unmotivated learners, coping with large classes, time demands, and lack of involvement in decision-making and emotional reactions such as depression.

According to Naidoo, Botha and Bisschoff (2013) in their study on causes of stress in public schools and its impact on work performance of educators, strenuous working conditions had a direct impact on educator stress resulting in poor performance. The findings of the seven factors which were organizational support, overload, remuneration, control, job insecurity, relationship and opportunities and growth opportunities also highlight the reasons why educators are considering quitting the profession.

Musyoka, Ogutu and Awino (2012), in a study on employees stress and performance of companies listed in the Nairobi Securities Exchange, factors within the organization such as work overload, difficult co-workers, too many responsibilities, demanding and unreasonable deadlines, conflicting demands and unclear expectations did not affect performance negatively. Lack of control over workload, demanding and difficult customers and office politics may have triggered positive stress, which in turn enhanced performance. A further study in Kenya on causes of burnout among secondary school teachers: a case of Bungoma North district, Kenya, by Sichambo, Maragia, Simiyu (2012) revealed that apart from the normal classroom teaching, teachers had a number of remedial lessons to attend to, larger classes to handle, a lot of paper work and some had to stay in their work stations other than their normal school timings in order to complete various tasks. All these factors were contributing to burnout among teachers which were badly impacting their performance. Studies reviewed by Santiago et al (2008) in Espania and Duyilemi in Nigeria and Sichambo, Maragia, Simiyu (2012) and Yambo, Kindiki and Tuitoek (2012) in Kenya have shown that school routines, workload, paperwork and students disruptive behaviour contributes to teachers' stress. However, the studies did not address the influence of school factors on stress among teachers in secondary schools in Kakamega sub-county.

In Malaysia, in a study on occupational stress and turnover intentions among school teachers in Negeri Sembilan by Salahudin, Abdullah and Hitam (nd) revealed that the teachers with higher salaries in the schools would experience more stress compared to lower income teachers. In the schools context, teachers with higher salaries are occupied with more responsibilities and duties which could increase their stress level. Teachers who were getting salaries more than RM 4000 demonstrated the lowest level of stress because they felt more secured in their career. They further revealed that those teachers who had higher qualifications experienced higher stress due to the fact that: they are looking or considering other opportunities in deciding their career path.

In a study on an empirical study of stressors that impinge on teachers in secondary schools in Swaziland, Okeke (2013), the major stress teachers and this component included the lack of power and influence, threat of job losses, performance related incentives, poor pay, lack of accommodation, badly planned changes, temporary contracts, and shortage of teachers. Poor pay, lack of accommodation, temporary contracts among other factors has been mentioned as factors causing stress.

In Pakistan, teachers under stress cannot perform well. Their job satisfaction and motivation levels are decreased and they show unwanted behaviors like absenteeism, mistakes during work and violence at work. Furthermore they have more health related physical and psychological complaints. Their students' satisfaction level is also deceased in such way that they cannot impart quality instructions to the students. Resultantly, complaints come from parent and employers' side, which have hired students as their employees thus the overall image of the educational institution gets damaged (Khan et al, 2012). Further study by Bibi et al (2012), on the nature and impact of teacher stress in the private schools of Gilgit-Baltistan, Pakistan, teachers' salary increases and promotions are tied with their annual performance rating determined through their appraisal system and that is why teachers take the appraisal system very seriously. Their discussions with the teachers reflected the fact that teachers were highly dissatisfied with the issues of transparency and fairness with which the appraisal is conducted. Most of the teachers complained that there is no justice done by the supervisors in the appraisals. They also shared that the supervisors decide on teacher rating only based on one or two classroom observations during the entire year. Teachers consider this kind of decisions very unfair. In addition, the school heads have a role in teacher appraisal. However, they told us that in most cases heads themselves lack the capacity and are less skilled and knowledgeable than the teachers they assessed. Further study on effect of salary and stress on job satisfaction of teachers in Sialkot District, Usman, 
Akbar, Ramzan (2013) found out that financial rewards (salary) significantly affect job satisfaction. It means that if employees are not given proper salary in time, they would be highly dissatisfied with their jobs and may ultimately start thinking of leaving the profession. This is due to the fact that cost of living is highly increasing in Pakistan.

Govindarajan's (2012) study on the level of stress and coping strategies among primary teachers in Tamilnadu, found out that the main source of the stress as pointed out and identified is the changing education policies of the government. The most effective coping mechanism according to them is to have a healthy home life. Teachers reported that the most effective action that schools or the Government can take to reduce teacher stress is to increase teachers' salary and fortunately, the government has announced the implementation of 6th pay commission for teachers. This will support the result of this study, Govindarajan (2012). This study focused on levels of stress among primary teachers and found out that the main source of stress is education policies. However, it did not address the influence of the education policies and other employment factors on stress among secondary teachers.

In Taiwan, Kyriacou and Chien (2004) in their study on teacher stress in Taiwanese primary schools, the main source of stress identified was the changing education policies of the government. The most effective coping action reported was having a healthy home life. Teachers reported that the most effective action that schools or the government could take to reduce teacher stress was to decrease teachers' workload. This study used questionnaires to collect the data. However, the research design was not indicated. It is therefore difficult to authenticate the results. In assessing sources of stress, the study used a question that had 20 items, the questionnaire was not exhaustive. The study focused on stress among primary teachers. However, stress among secondary teachers was not addressed, the study also did not indicate the actual contribution of these factors on stress among teachers, a knowledge gap that the current study sought to fill.

In a study carried out on Bihar and Jharkhand universities by Kumar and Deo (2011) on stress and work life of college teachers, it was found that junior college teachers experienced significantly higher level of stress on role overload, role stagnation and interpersonal relation and on overall stress in comparison to senior teachers. The senior teachers were more satisfied with their job and life in comparison to junior colleagues. The reason is red tapism and unnecessary delay in Promotion Avenue as well as shifting workload to junior colleague. Alam and Farid (2011), in their study on factors affecting teachers' motivation in Rawalpindi city, concluded that teachers were not satisfied with their socio economic status, choice of profession, student's behavior and examination stress. A number of teachers felt that they were not paid according to their abilities. It was recommended that teachers should get teacher training, should be given due respect and should be paid according to their qualifications and abilities.

In India, in a study on demographic differences and occupational stress of secondary school teachers, Aftab and Khatoon (nd) concluded that nearly half of the teachers are in less stressed group and male teachers face more occupational stress than their counterparts. Further, it was revealed from the result that trained graduate teachers have significantly higher occupational stress than post-graduate and untrained teachers. The study also finds that occupational stress is most prevalent among teachers with an experience of 6-10 years and least among 0-5 years of experience in teaching. Further, no significant difference is seen between the monthly salary and occupational stress of secondary school teachers. Also, no significant difference is found among the teachers teaching languages, arts, social sciences and sciences. In addition to this, the study also supports no significant difference in the marital status and occupational stress of secondary school teachers.

Maphalala (2014) in his study on the manifestation of occupational stress in the teaching profession: the unheeded voices of teachers in KwaZulu Natal province, South Africa revealed that teaching stressors which the teachers found stressful, in order of most to least stressful, were curriculum changes, work load pressures and job insecurity. This study adopted a descriptive research design. Questionnaires were used to collect data. This study focused on occupational stress among primary teachers. However, it did not address stress among secondary teachers, a knowledge gap that the current study sought to fill.

Ekundayo and Kolawole (2013), in their study on stress among secondary school teachers in Ekiti State, Nigeria, revealed that poor working conditions, poor relations with super ordinates and late payment of teachers' salaries were major sources of stress among teachers in the state. The study also revealed that organizing one's time effectively is the main strategy of coping with stress among the teachers. The study further revealed a significant relationship between sources of stress and the teaching effectiveness of the teachers. Duyilemi (nd) in his study on source and social correlates of occupational stress among Nigerian primary school teacher found out that the teachers perceived delay in promotion as their second greatest stress factor. This should be expected since some of the sample teachers (especially those from Rivers and Imo) complained of being on the same salary level for about 6 years.

In a study on teachers, remuneration and performance of schools under Universal Primary Education system in Uganda: a case study of Wakiso District, Barbara (2011) found out that the relationship between teachers' remuneration and performance of schools under Universal primary education system revealed a strong and positive relationship between teachers' remuneration and performance of schools under Universal Primary Education system. 
In Kenya, Wangai (2012) in her study on factors affecting job satisfaction among secondary school teachers of Mwatate District, Kenya found out that salary level was ranked as the most important factor towards job satisfaction and poor pay as the most dissatisfying job factor. Further, in a study on institutional factors that influence teacher turnover in public secondary schools in Baringo district, Kenya, Koech, Tikoko and Chemwei (2014) concluded that remuneration, career advancement and working conditions were the domains mostly responsible for the teacher turnover in Baringo district secondary schools. On the whole, the study found that institutional factors influence teacher turnover in Baringo District. In a study on causes of burnout among primary school teachers within Kericho municipality, Kenya, Ng'eno (2007) found that low salaries, lack of involvement in decision making, heavy work load and few opportunities for promotion were the main contributory factors to teacher burnout within the municipality. The study used survey research design. Stratified and simple random sampling techniques were used to select the sample. Studies reviewed by Kyriacou and Chien (2004) in Taiwan, Usman, Akbar, Ramzan (2013) in Sialkot district and Govindarajan, (2012) found out that government policies, salary and promotion are sources of stress in teaching. However, these studies did not address the influence of government policies, salary and promotion on stress among secondary teachers in Kakamega North sub-county.

In Kenya, Kendi (2012) in her study on impact of occupational stress on head teachers' tasks in secondary schools of Kisumu County, Kenya found out that all head teachers receive stress from their position of headship, stakeholders and their families. Kendi (2012) in Kenya focused on head teachers and found out that they receive stress from their families, however, the study was limited to head teachers and did not address teachers in general. Studies reviewed by Darmody and Smyth (2001) in Ireland found out that job stress did not vary by gender. However, Abirami (2012) found out that female teachers have perceived maximum level of job stress than male teachers, while Okeke and Diamin (2013) found out that there was a weak relationship between the level of work related stress and the demographic variables of gender, marital status and qualifications. However, these studies did not address the influence of familial factors on stress among teachers in Kakamega North sub-county.

\section{CONCEPTUAL FRAMEWORK}

The conceptual framework (Figure 1.1) is based on Zedan and Bitar (2012) concept that there are factors that cause stress among teachers such as overloaded classes, lack of teaching resources, violence, inconvenient working conditions. This conceptual framework postulates that workload; school environment and government policies can stress a teacher. Once a teacher is stressed, he/she can be affected positively or negatively.

\section{Independent Variables}

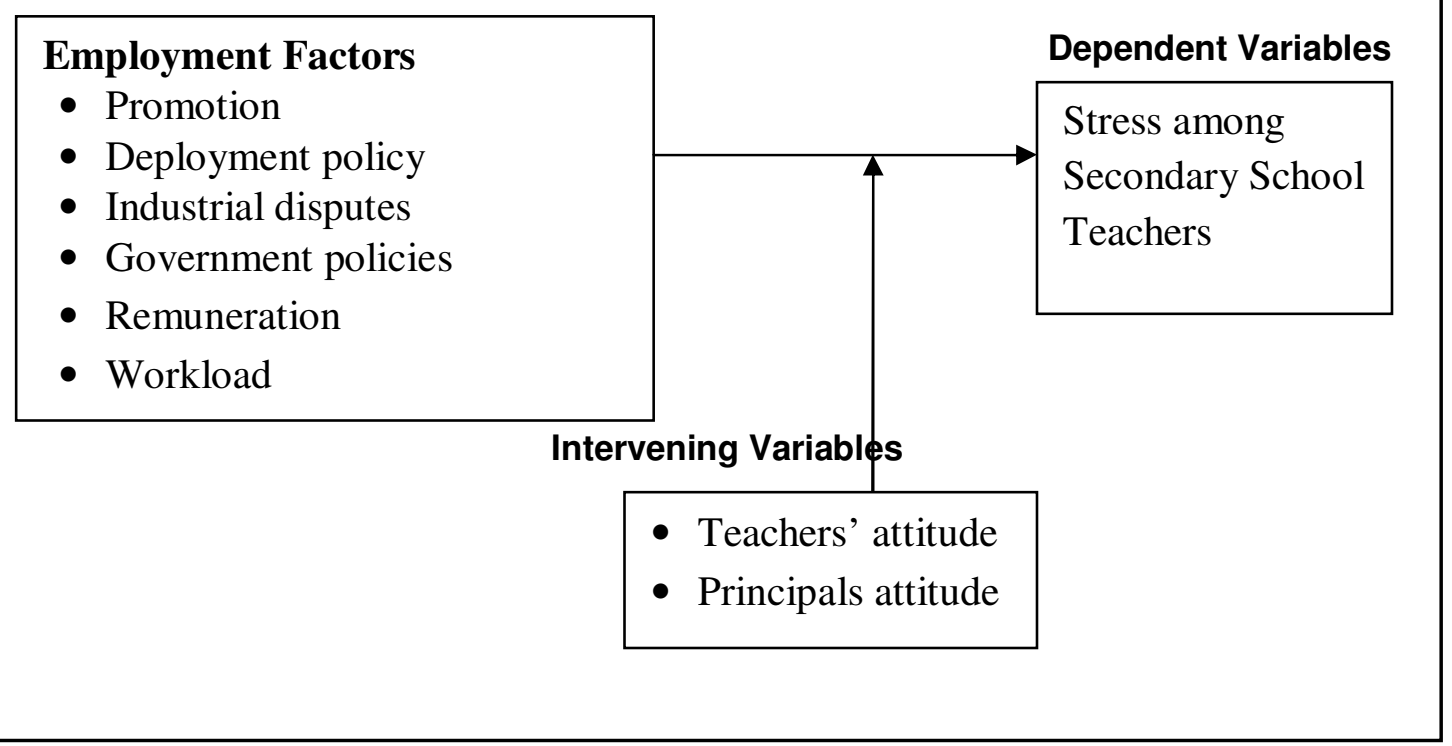

Figure 1: A Conceptual Framework Showing the Influence of Employment factors on Teachers' Stress 
A teacher that is well paid, has manageable workload, consulted and involved in making decisions on policies, teaches well behaved students, receives support from the administration and given promotions will experience more or less stress. When a teacher is having a big load that he/she is not able to handle, a large class, no promotion, not involved in decision making and more children, the teacher is also likely to experience more or less stress. Whichever way, the stress experience becomes critical when it moves towards burnout. It is important to note that stress is tension, pressure and anxiety that is highly correlated with psychological well-being of a person and is sometimes confused with the physical well-being of persons. In fact, the physical well-being of a person is partly the product of psychological well-being. Consequently, psychological well-being of a teacher is highly correlated with the physical well-being of that teacher. Stress disrupts the psycho-physical equilibrium of a person, that is, our bodies and minds should be in a state of equilibrium for normal functioning, but when external stimulus sets in, it interferes with this state. Nevertheless, for teachers the influence is dependent on the teachers' and principals' attitudes among other factors. These two factors mediate the influence of stressors on levels of stress among teachers.

\section{RESEARCH METHODOLOGY}

The study adopted descriptive survey and correlational research designs. The study population consisted of 45 principals, 133 teachers and one Teachers Service Commission County Director. The study used saturated sampling technique to select 40 principals and one Teachers Service Commission County director. Purposive sampling technique was used to select 99 teachers of the form four 2014 students. Quantitative data was collected using questionnaires and document analysis guide, while qualitative data was collected using interview schedules. Data was collected by use of questionnaires, interview schedules, and document analysis guide. Face and content validity of the instruments was determined by experts in the area of Educational Administration whose input was incorporated in the final instruments before going to the field. Reliability of instruments was established through a test re-test method in $5(10 \%)$ of the schools that were not involved in the main study whereby Pearson's $r$ coefficient of 0.7 and above at a set $p$-value of 0.05 was considered reliable. In this case the Pearson's $r$ coefficient for teachers' questionnaire was 0.89 , hence the instrument was declared reliable. Quantitative data from closed-ended items of the questionnaire was analyzed using frequency counts, percentages and means in order to establish the stress levels. Regression analysis was used to establish the influence of employment factors on the levels of stress among public secondary school teachers. Qualitative data from the open-ended items in the questionnaire and interviews were transcribed and analyzed in emergent themes and sub-themes. 


\section{RESULTS}

\section{Demographic Characteristics of the Teachers}

The demographic data of teachers were as shown in Table 1.

Table 1 Demographic Characteristics of the Teachers $(n=99)$

\begin{tabular}{|c|c|c|}
\hline Demographic Characteristics & $\begin{array}{l}\text { Frequency } \\
\text { (F) }\end{array}$ & $\begin{array}{l}\text { Percentage } \\
(\%)\end{array}$ \\
\hline \multicolumn{3}{|l|}{ Gender } \\
\hline Male & 60 & 60.6 \\
\hline Female & 39 & 39.4 \\
\hline Total & 99 & 100 \\
\hline \multicolumn{3}{|l|}{ Marital Status } \\
\hline Married & 62 & 62.6 \\
\hline Single & 26 & 26.3 \\
\hline widow & 3 & 3.0 \\
\hline widower & 5 & 5.1 \\
\hline Divorced & 3 & 3.0 \\
\hline Total & 99 & 100 \\
\hline \multicolumn{3}{|l|}{ Age in Years } \\
\hline $20-29$ & 23 & 23.23 \\
\hline $30-39$ & 23 & 23.23 \\
\hline $40-49$ & 32 & 32.32 \\
\hline 50 and Above & 21 & 21.22 \\
\hline Total & 99 & 100 \\
\hline \multicolumn{3}{|l|}{ Highest Level of Education } \\
\hline Diploma & 12 & 12.12 \\
\hline $\begin{array}{l}\text { Bachelor of Education } \\
\text { Bachelor of Science and Post } \\
\text { Graduate Diploma in Education }\end{array}$ & $\begin{array}{l}54 \\
21\end{array}$ & $\begin{array}{l}54.54 \\
21.22\end{array}$ \\
\hline Masters & 12 & 12.12 \\
\hline Total & 99 & 100 \\
\hline \multicolumn{3}{|l|}{ Teaching Experience } \\
\hline$<5$ years & 12 & 12.12 \\
\hline $6-10$ years & 29 & 29.29 \\
\hline $11-15$ years & 35 & 35.35 \\
\hline 16 and above & 23 & 23.23 \\
\hline Total & 99 & 100 \\
\hline
\end{tabular}

Sixty $(60.6 \%)$ of teachers were male and $39(39.4 \%)$ were female. This means that majority of the teachers in the sub county were male. Sixty two $(62.6 \%)$ of the teachers were married, $26(26.3 \%)$ were single, 5(5.1) were widowers, $3(3.0)$ were widows and $3(3.0 \%)$ were divorcees. This means that majority of the teachers were married. The study also sought to investigate the ages of the teachers. The study categorized the ages of the respondents into four age brackets; Age bracket $20-29$ had 23 (23.23\%) respondents, 30-39 had 23(23.23\%) respondents, and 40-49 had $32(0.32 \%)$ respondents and 50 and above had $21(21.22 \%)$ respondents. It can be concluded that a majority of the respondents were in the age bracket 40-49. This is the age when most parents have a responsibility of raising their children. The study also sought to investigate the level of education of the teachers. The information was 
important as it helped in gauging the responses of the respondents. Majority of the teachers had Bachelor degree in education, that is $54(54.54 \%)$, Bachelor of Science and Post Graduate Diploma in Education were 21(21.22\%), twelve (12.12\%) had Masters degrees, while $12(12.12 \%)$ had diploma degrees. The study sought to determine the teaching experience of the teachers. The teaching experience was categorized into four categories that is, $<5$ years, 6-10 years, $11-15$ years, 16 and above years. The results showed that $12(12.12 \%)$ teachers had less than 5 years of experience, $29(29.39 \%)$ teachers were in the bracket of 6-10 years of experience, $35(35.35 \%)$ were in the bracket of $11-15$ years of experience and lastly $23(23.24 \%)$ were in bracket of 16 and above years. This means majority of the teachers have taught for 6-10 years. The information on experience was important as the more experienced teachers were, the higher their ability to understand the students better. The demographic information enabled as to get balanced information as we had teachers in all the categories, that is, single, married, widows, widowers and divorcees.

\section{Research Hypothesis}

The research hypothesis was: There is no statistically significant relationship between employment factors and teachers' stress levels among public secondary school teachers.

To respond to this research hypothesis, levels of stress among secondary school teachers and the influence of 25 factors were first measured and computed. The results were as shown in Tables 2 and 3.

Table 2: Stress Levels of Secondary School Teachers $(n=99)$

\begin{tabular}{lccc}
\hline Stress Levels & Ratings on 5 -point scale & Frequency & Percentage \\
\hline Very low & $1.00-1.44$ & 00 & 00.00 \\
Low & $1.45-2.44$ & 06 & 06.06 \\
Moderate & $2.45-3.44$ & 37 & 37.37 \\
High & $3.45-4.44$ & 56 & 56.57 \\
Very high & $4.45-5.00$ & 00 & 00.00 \\
Total & & 99 & $\mathbf{1 0 0 . 0 0}$ \\
\hline
\end{tabular}

From Table 2 it can be noted that 6(60.6\%) teachers were experiencing low stress level, $37(37.37 \%)$ were moderately stressed, while 56(56.57\%) were highly stressed. Overly the mean stress level was 3.44 and standard deviation was 1.403 . This means that the teachers in Kakamega North Sub-county were experiencing moderate stress.

The study further sought to establish the influence of the 25 factors /life events on levels of stress among the secondary school teachers. The results were as shown in Table 3. 
Table 3: Influence of Employment Factors on Stress among Teachers

\begin{tabular}{|c|c|c|c|}
\hline Item & Factors /Life event & Mean & $\begin{array}{l}\text { Standard } \\
\text { Deviation }\end{array}$ \\
\hline 1 & Teachers job groups /salary & 4.10 & 1.216 \\
\hline 2 & Career development opportunities & 2.34 & 1.341 \\
\hline 3 & Teachers' dress code & 1.97 & 1.120 \\
\hline 4 & Teachers' promotion policy & 4.05 & 1.232 \\
\hline 5 & Role conflict & 4.04 & 1.251 \\
\hline 6 & Teachers involvement in Government policy decisions & 2.43 & 1.385 \\
\hline 7 & Government policy on cheating in the examination decisions & 3.00 & 1.065 \\
\hline 8 & Teachers' medical allowance & 4.09 & .838 \\
\hline 9 & Teachers' house allowance & 4.15 & .983 \\
\hline 10 & Teachers' commuter allowance & 4.09 & 1.006 \\
\hline $\begin{array}{l}11 \\
12\end{array}$ & $\begin{array}{l}\text { Government decision on teachers' strikes } \\
\text { Study leave policy }\end{array}$ & $\begin{array}{l}4.43 \\
4.52\end{array}$ & $\begin{array}{l}.989 \\
.876\end{array}$ \\
\hline 13 & Retirement policy & 4.41 & .972 \\
\hline 14 & HIV and Aids policy & 2.73 & 1.136 \\
\hline 15 & Staffing policy & 2.89 & 1.157 \\
\hline 16 & Workload & 3.74 & 1.394 \\
\hline 17 & Deployment policy & 3.19 & 1.277 \\
\hline 18 & Teacher transfer policy & 4.29 & 1.190 \\
\hline 19 & Five year employment policy & 3.78 & 1.515 \\
\hline 20 & $\begin{array}{l}\text { Policy on invigilation of Kenya National Examination councils } \\
\text { examinations }\end{array}$ & 1.97 & 1.388 \\
\hline 21 & Sick leave policy & 2.07 & 1.139 \\
\hline 22 & Maternity leave policy & 2.59 & 1.337 \\
\hline 23 & Annual leave policy & 2.58 & 1.345 \\
\hline 24 & Working hours & 2.74 & 1.244 \\
\hline \multirow[t]{2}{*}{25} & Paternity leave policy & 2.54 & 1.291 \\
\hline & Overall Mean & 3.31 & 1.187 \\
\hline
\end{tabular}

\section{Interpretation of Means:}

$1.00-1.44=$ Very low influence

3.45-4.44 = High influence
$1.45-2.44=$ Low influence

4.45-5.0 = Very high influence
2.45-3.44 = Moderate influence

From Table 3, it can be observed that $5(20 \%)$ factors had low influence on levels of stress among secondary school teachers. These included: Teachers dress code, teachers involvement in government policy decisions, government policy on cheating in examinations, Kenya National Examination Council policy on invigilations of examinations and sick leave policy. Eight (32\%) factors had moderate influence on teachers stress. These included: career development opportunities, HIV and AIDs policy, staffing policy, deployment policy, maternity leave policy, annual leave policy, working hours and paternity leave policy. Eleven (44\%) factors had high influence on teachers' stress. These included: Teachers job groups/salary, promotion policy, role conflict, medical allowance, house allowance, commuter allowance, study leave policy, workload, transfer policy and five year employment policy. Government decision on teachers' strike (4\%) had very high influence on teachers' stress.

The study went further to establish relationship between employment factors and teachers stress level. 
Table 4: Relationship between Employment Factors and Teachers Stress

\begin{tabular}{llc} 
& & Teachers stress \\
\hline Employment factors & Pearson & .343 \\
& Correlation & \\
& Sig. (2-tailed) & .001 \\
& $\mathrm{~N}$ & 99 \\
\hline
\end{tabular}

From Table 4, it can be observed that there was a weak positive relationship between employment factors and teachers stress levels. The relationship was significant as the calculated p-value was .001, which was greater than the critical value .05. This means that increase in employment factors would lead to increase in stress levels among public secondary school teachers. To estimate the influence of employments factors on teachers stress regression analysis was done and the results were as shown in Table 5.

Table 5: Regression Analysis of the Influence of Employment Factors on Stress among Teachers in Public Secondary Schools

\begin{tabular}{lcccc} 
Model & $\mathbf{R}$ & $\begin{array}{c}\mathbf{R} \\
\text { Square }\end{array}$ & $\begin{array}{c}\text { Adjusted } \mathbf{R} \\
\text { Square }\end{array}$ & $\begin{array}{c}\text { Std. Error of the } \\
\text { Estimate }\end{array}$ \\
\hline 1 & $.343^{\mathrm{a}}$ & .118 & .109 & .446291
\end{tabular}

a. Predictors: (Constant), Employment Factors

From Table 5, it can be observed that employment factors accounted for $10.9 \%$ of teachers' stress level. Eighty eight point two percent $89.1 \%$ was due to other factors that were not investigated by these factors. To determine whether employment factors were significant predictors of teachers stress, ANOVA was computed and the results were as shown in Table 6.

Table 6: Analysis of Variance on the Influence of Employment Factors on Stress among Teachers in Public Secondary Schools

\begin{tabular}{llccccc}
\hline & Sum of & \multicolumn{4}{c}{ Mean } \\
& Model & Squares & Df & Square & F & Sig. \\
\hline 1 Regression & 2.582 & 1 & 2.582 & 12.964 & $.001^{\text {D }}$ \\
Residual & 19.320 & 97 & .199 & & \\
Total & 21.902 & 98 & & & \\
\hline
\end{tabular}

a. $\quad$ Dependent Variable: Teachers Stress level

b. Predictors: (Constant), Employment factors

From Table 6, it can be observed that employment factors are significant predictors of stress among secondary teachers in Kakamega North sub-county $(\mathrm{F}(1,97=12.964<.05)$.

The study then sought to determine the actual influence of employment factors on teachers' stress level. Linear regression analysis was computed and the results were as shown in Table 7. 
Table 7: Linear Regression of Employment Factors and Teacher Stress.

\begin{tabular}{|c|c|c|c|c|c|c|}
\hline & \multirow[b]{2}{*}{ Model } & \multicolumn{2}{|c|}{ Unstandardized Coefficients } & \multirow{2}{*}{$\begin{array}{c}\begin{array}{c}\text { Standardized } \\
\text { Coefficients }\end{array} \\
\text { Beta } \\
\end{array}$} & \multirow[b]{2}{*}{$t$} & \multirow[b]{2}{*}{ Sig. } \\
\hline & & B & Std. Error & & & \\
\hline \multirow[t]{2}{*}{1} & (Constant) & 2.127 & .366 & & 5.812 & .000 \\
\hline & $\begin{array}{l}\text { Means Employment } \\
\text { Factors }\end{array}$ & .395 & .110 & .343 & 3.601 & .001 \\
\hline
\end{tabular}

a. Dependent Variable: Teachers Stress : Regression equation $Y=a+b X$

From Table 7, it can be observed that one unit increase in influence in employment factors would lead to increase in stress among teachers of public secondary schools by .395 units. The regression equation is $Y=2.127+.395 X$

\section{DISCUSSION}

The Basic Education Act 2013, Teacher Service Commission Act 2012, Labour Laws 2007 and the Constitution of Kenya 2010 regulate operations of the teaching profession. For majority of teachers, these legislations coupled with reorganization of the education system mean a lot. The reorganization is associated with many challenges, positive and negative, which culminate in stress for teachers. Once a newly qualified teacher joins the teaching profession, he is automatically subjected to the following demands and challenges: Job categorization, Employers rights, career development opportunities, dress code, salary incremental credits, policy formulation, examination, decision making compensation rights, policies and privileges among others.

The study established that teachers are contracted to serve anywhere in the country where their services are most needed. Entry into a school as a newly employed teacher and transfer of a teacher from one school to another presents more or less the same challenge. First it means leaving the security of a familiar environment, working either in a larger and more complex school or a smaller school; teaching students who have a much wider range of abilities, behaviour and attitudes; and adapting to major organizational and curricular changes. Some of these changes become threats and are viewed with apprehension, which makes teaching stressful. This is because some schools are managed and administered by benevolent autocratic father-figures who are highly dreaded. This means that for some teachers, they find it difficult to develop the sense of belonging to the school due to slow and uneasy process of adjusting to the new institution. This manifests in very large schools where there is a risk that the school is perceived as so impersonal and so fragmented that a sense of common purpose is very difficult to achieve. In these circumstances, it becomes difficult to find points of identification with fellow teachers and students. For teachers who previously had served in small schools where they felt the job satisfaction was shared become depressed. What stresses them are aspects like split-site working, complicated disciplinary procedures, impersonal communication systems and new administrative structures which include executive teams, policy and planning committees and staff working parties. These teachers are also disturbed by the intensity of their own emotional reactions in classrooms, laboratories, and staffrooms. These findings concur with those of Anbu (2015) who in a study titled professional stress of higher secondary school teachers in Nagercoil Region, India established that professional stress is often associated with overachievers. High levels of self-induced stress usually characterize this individual stress. However, it is also associated with under load institutions. That is job underload may also create higher levels of anxiety, depression and physical illness than job overload due to long period of boredom. The demands made on the teachers are compounded in many schools by school ethos. The onus is on the teachers to cope with students of both sexes, all ages and abilities, with a plethora of new methods, curricular and attitudes which often are stressful.

The stressors are not staggered to give teachers the opportunity of adjusting to one after another before coping with the next one. They are rather simultaneous. Pressures arising from the many different kinds of stressors are perpetual. These stressors include low salaries, delayed promotions, cheating in examinations, low house allowances, meager commuter allowances, heavy workload, unfriendly personnel policies and poor medical schemes.

Many teachers indicated they were unable to gain further promotion. This had led to discontent among teachers, which affects their interpersonal relations with the hierarchy. The situation is worsened in cases where the principals and their deputies share out their workload to teachers who already felt frustrated at their inability to gain promotion.

This findings concurs with those of Sichambo, Maragia and Simiyu (2012) who in their study on causes of burnout among secondary school teachers in Bungoma North Sub-county, Kenya revealed that apart from normal 
classroom teaching, teachers had a number of remedial lessons to attend to, larger classes to handle a lot of paper work and some had to stay in their workstations beyond normal class time in order to complete various tasks delegated to them by principals. Wangai's (2012) study titled factors affecting job satisfaction among secondary school teachers of Mwatate District, Kenya supports these findings by indicating that poor pay was the most dissatisfying job factor. Mark you promotion has a high correlation with medical allowances, commuter allowances and house allowances.

The expansion of the education sector has led to growth of urgent financial problems. The relative costs in educational expenditure were imposing serious pressures. These pressures included reductions in staffing at all levels in educational institutions, a virtually complete embargo on all appointments, the restriction of building, repairs and maintenance; and failure to review salaries periodically as required by labour laws. Two other important stressors are staff allocation and redeployment. For the last three decades schools have experienced increase in access and suffered relative cuts in public spending, which has led to reduced staffing allocation for schools. This has led to employment of teachers on temporary terms by Boards of Managements, who are poorly paid. The redeployment stressor undermines the confidence of the teacher since the teacher may be "passed on" and depending on the attitudes of principals who are the recipients. Hence in some cases, redeployment becomes traumatizing. The effect of redeployment on the school as a whole should also be considered, because the pressures do affect more people than is at first apparent. During the interview, one of the principals stated: "The following problems have been experienced when going through the redeployment procedures: first the identified staff feels rejected by his school, he feels he is no good and that he has no future in the profession. This is emotional and traumatic to the families of the affected teachers. Secondly, the colleagues to the affected staff feel guilt and uncertain on how to react. Thirdly, the relationship between the teacher and senior colleagues is destroyed, particularly when the teacher is surrendered".

The government's decisions and reaction to industrial action (Teachers' strikes) had made teachers to feel resentful, depressed and devalued, with the consequence that some had committed suicide. What was common place is that there is considerable rise in the levels of stress experienced by teachers. Frustration is caused by an increase in summons by principals, and teachers were not so cooperative. In fact, one teacher wrote in the questionnaire "You feel so bloody insulted that the principal is telling you, you are a lazy, slow learner and need to be retrained." Another teacher wrote "I am stressed because of my colleagues' growing disillusionment with the teaching job. For instance, two of my fellow teachers are leaving teaching without having a job to go to." These findings concur with the findings of Anbu (2015), Gebrekirtos (2015), and Sultana, Bano, Bano and Shafa (2012) whose findings indicated that the teaching profession is stressful. Anbu (2015) asserts that stress means pressure, tension or worry resulting from problems in one's life and is considered as a factor of several illnesses.

According to him environmental events, interpersonal conflicts or personal deficiencies trigger off stress. Professional stress means the difficulty experienced by teachers working in educational institutions. Professional stress is often associated with overachievers and underachievers, triggered by high level of achievement and boredom due to underload respectively. Gebrekirstos (2015) emphasizes that studies have suggested that teachers perceive their profession as a major stressful work situation compared to other professions. He adds that interpersonal, organizational and students problems trigger off stress. Sultana, Bano, Bano and Shafa assert that stress factors were inextricably connected with the professional, personal and financial dimension of the teacher's life. It is important to note that the major pressures of stress are the increasing complexity and accountability of the job, for instance, performance contracting which principals of schools are being compelled to sign and the demands by parents on teachers to produce excellent students academic performance. There is lack of forward planning and discussion on how to handle these issues in the best way possible. The marked changes in parents' and students' attitudes are stressful. They need more counseling and support. This is because parents and students are challenging the school rules and regulations more frequently and even harassing teachers in the classroom during teaching time. Principals also demand more from teachers to cover the syllabus in time. The teachers have no free time from class even though some of them have additional administrative and consultant responsibilities. The emphasis on excellent Kenya Certificate of Secondary Examination results has brought radical change to the role of teachers. The essential requirements of excellent performance are regular assessments which involve new approaches of working for many members of staff. The changes have resulted in increased paperwork, meetings, workshops, benchmarking and moderation of assessments. The teachers were of the perception that the pressure was becoming unbearable, emanating from many sources, that is, the government, parents, Boards of Managements, the media, local authorities, and pressure groups to put teachers on performance contract and retraining. These gestures are perceived as strong indicator that the values which should guide teachers' performance of their roles are those of market place economics, that is, cost -effectiveness, cost-cutting, profit and increased efficiency. The central theme is value for money. All these demands coupled with meagre financial resources and shortage of staff has made teaching stressful. 
Role conflict is a major stressor in the teaching profession. In this respect one of the teachers noted; "I am expected to meet different and conflicting roles at once. For instance those of a counselor, a social worker, a parent, a disciplinarian and a role model. To keep my sanity and my priorities right I always remind myself that I was trained and licensed to teach, impart knowledge, and that in no way should I be compelled to deal with students' personal matters." Another teacher remarked "I believe it is unethical to know too much about students. Of course I cannot ignore a disruptive or depressed student but I always make sure I am not too involved." Notwithstanding these views of teachers, it is in public domain that the teachers' roles have expanded based on the argument that students' development: social, emotional, physical, moral, interpersonal and mental should be accepted as the responsibilities of teachers because teachers are in-loco-parentis. This is what is known as the "whole child approach." In a nutshell the role of the teacher has expanded to include that of social worker, psychiatrist, counselor, motivational arouser, policeman and many other roles. Indeed many teachers feel untrained and unable to deal with these pressures. Nevertheless the nature and work of a teacher is subject to these pressures and all the teachers' are required to develop and recommend appropriate measures to reduce stress resulting from these pressures. This could include smaller Student -Teacher Ratio among others. All these stressful events are compounded by lack of time, large classes, poor and shortage of teaching-learning resources, poor communication, lack of information, dilapidated infrastructure, low salaries, allowances and shortage of infrastructure.

Besides, the nature of the teaching profession in Kenya, legislative changes in the education sector, have contributed immensely to stress among teachers. Many of the changes are very positive, but the problem is implementation. For instance the Free Secondary Education policy, Re-entry policy, bursary scheme, curriculum changes, physical punishment ban, mental harassment ban, and the right to education and constitutional enactment. The implementation of these legislative changes is haphardly done and leads to disillusionment of teachers, which is highly demotivating and frustrating.

During the interviews with the Principals, it was revealed that teachers dressing code was not a big issue to them as they had been given a clear guideline on what they should wear. In this respect, one Principal stated:"Teachers are comfortable with their dressing code. With the modern times we are not very strict on what they wear. We want results. Those affected are those in Muslim schools. They are not restricted on what to wear but they feel odd one out when they don't dress appropriately in the current environment." The study findings also showed that maternity leave, paternity leave and sick leave had a low influence on stress among teachers in public secondary schools in Kakamega North sub-county. This could be because the leaves are granted anytime a teacher requires them as long as relevant documents are availed. It was revealed from open ended question that female teachers could go for maternity leave while male teachers could go for paternity leave, though they felt the leaves could start a little bit early to give them enough time to prepare for the new born. They also didn't have much of a problem with the leaves though they felt maternity leave should be given at least four months. Teachers' job groups and teachers' promotion policy had a high influence on stress among teachers. Moving from job group $K$ to $L$ is easy but teachers stagnate in job group $L$ for years and this stresses them so much. The lower the job group, the lower the salary. The findings from open ended question showed that many teachers had stagnated in the same job group for years and this stressed them so much. Teachers were also stressed by the fact that civil servants were promoted to the next group faster than them and the fact that civil servants in the same job group were earning more than them. During the interview with the Teachers Service Commission county director, it was revealed that teachers were stressed by the fact that teachers were promoted basing on their Kenya Certificate of Secondary Education Examinations results. Teachers need their commuter and medical allowance increased and that is the reason behind their strike. In this respect, the Teacher Service Commission County director stated: Teachers are very sensitive on what they put in their pockets. Poor pay and performance incentives do reduce the teachers' happiness in their work situation as well as their ability to perform. Money motivates a teacher. As much as there are other motivators, money becomes the most valued motivator by teachers and that is the reason behind so many strikes within the teaching profession in Kenya.

In this respect the Teachers Service Commission county director stated: Teachers in young schools feel disadvantaged as their mean grades are low. Their students' entry behaviour is sometimes below 250 marks yet when they go for an interview; they are forced to compete with teachers from old schools with good academic records.

These findings are in line with the finding of Santavirta, Solovieva and Theorell (2007), who found out that teachers experienced high levels of stress as a result of poor remuneration packages and fringe benefits in spite of the volume and challenging work that they do. These findings are also line with the findings of Dlamini, Okeke and Mammen (2014) in their study on an investigation of work-related stress among high school teachers in the Hhohho region of Swaziland that showed that high school teachers in the Hhohho region of Swaziland are moderately stressed.

The study also revealed that teachers' workload had high influence on stress among the teachers. Teaching profession is demanding as teachers have to attend to meetings almost on daily basis, and this makes them feel 
stressed, because it takes extra time. Teaching profession is always continuous; you never finish your work. It is a good job, but there is no end. The study revealed from open ended questions that majority of the teachers had twenty to twenty eight lessons per week. These were within the acceptable range according to the teachers' employer, Teachers Service Commission. However remedial teaching, holiday and weekend tuition, class discussions and intensive testing policies have added to the teachers' workload making work overwhelming. This causes stress and eventually burnout. During the interviews with the Principals, it was clear that teachers were comfortable with workload of 20 lessons and below. Above 20 lessons stresses the teacher. For instance, one Principal said: "Before I was given this responsibility, I used to feel more like a social worker than a teacher, with the amount of attention these students demanded from me. I used to handle 28 lessons at the same time deal with students' issues. I used to get stressed and I even thought of leaving the profession. Stress resulting from work overload could be attributed to the introduction of the new curriculum, understaffing or poor teacher-pupil ratio." Another Principal stated: "We are understaffed in our school. A teacher is forced to handle more than 25 lessons. Most teachers complain that they don't have life of their own. Every night, every weekend, they are grading, planning, communicating with parents and they miss having life on their own."The TSC County director said: "Many teachers want to leave the teaching profession. They complain that they report to school at 7 am and don't leave the school until at least $4.30 \mathrm{pm}$ and sometimes later and often take some extra work home to finish. By the time they are done, they are very tired."

The study findings are in line with Allan, Chan, Elaine (2009) in their study on work stress of teachers from primary and secondary schools in Hong Kong that heavy workload was the most frequently reported source of stress. The results also support the findings of Kyriacou and Chien (2004) in their study on teacher stress in Taiwanese primary schools that the dominant sources of stress in Taiwan appear to be a heavy workload and coping with educational reforms. Karaj and Rapti (2013) teacher job stress in Albania: examining the role of students' classroom disruptive behavior and other factors in the school context, workload was found to be significant predictors of teachers' job stress.

Inadequate salaries cause a great deal of stress, especially when taking into account the sacrifices they make to ensure that students do well in National examinations. That is perhaps the reason why some teachers embark on second jobs, mostly to the detriment of the school and the learners. Others look for other propositions and change to completely new jobs for the sake of better incomes. With the high cost of living, teachers rely on the medical allowance, teachers' house allowance and commuter allowance to boost their net salary. However, teachers are stressed because civil servants in the same Job group earn more than them. During the interviews, one Principal stated: "We have had so many strikes; the main reason is we need money. We cannot be earning lesser than the civil servants. Civil servants earn more commuter allowance, house allowance and medical allowance." These findings are in line with the findings of Education International European Trade Union Committee for Education (1999) on stress that teachers are not remunerated according to the same salary scale as a majority of other professions, and this weighs heavily upon them financially and sends a message that there work is not highly valued. The findings are also in line with findings of Okeke and Dlamini (2013) in their study on an empirical study of stressors that impinge on teachers in secondary schools in Swaziland study revealed contractual problems as the major stressor for teachers and this component included the lack of power and influence, threat of job losses, performance related incentives, poor pay, lack of accommodation, badly planned changes, temporary contracts, and shortage of teachers.

On the five year employment policy for new teachers, the study findings showed that many teachers wished to transfer to other schools, but the contract of five years had tied them up. Teachers are forced to be in an environment that is not conducive and this really stresses the teacher. Information from documents analyzed showed that majority of teachers had been in their stations for three and more years. Facing the same routine and challenges for long was monotonous. These teachers had requested for transfers but had not been granted. It was further revealed from open ended questions that most teachers who had requested for a transfer were much stressed. Exposure to new work experiences would revitalize the teachers. It was further established that teachers were mainly stressed due to the following: fear of being voluntary transferred to another school due to rightsizing and rationalization. The study findings also showed that the decision of the Government on teachers strike has a high influence on stress among teachers in Kakamega North sub-county. The decision of the Government to withhold teachers September pay (2015) really stressed teachers as they had to get loans for their upkeep. Teachers also feel that the Government has a negative attitude towards teaching profession and this stresses them. During the interviews with the Principals, it emerged that the Government stand on teachers' salary had really demoralized teachers and most of them were planning to leave the profession in future. Teachers rely on their pay for everything and so the issue of sourcing money for upkeep from other sources really stressed them.

The study findings also showed that an achievement of a master's degree incremental credit had a high influence on stress among teachers in public secondary schools in Kakamega North sub-county. Teachers want to better their lives. They want better pay and that is the reason behind most of them going back to school. It was found 
out from open ended questions that teachers who had achieved a master degree were very stressed as they had not received their increment. They had hoped that achieving an extra degree will assist them earn slightly higher but they had achieved nothing. They were paying loans they had taken to educate them. They wished they could have bought plots with the money.

The study findings also showed that eight out of 25 factors had a moderate influence on stress among teachers in public secondary schools in Kakamega North sub-county. These are: policy on exam cheating, HIV policy, staffing policy, deployment policy, working hours, paternity leave policy and maternity leave policy and annual leave policy. The findings showed that teachers were moderately stressed by the number of hours they attend to school activities. An employee's desire for performing better diminishes when he is forced to sit for long hours and his level of stress increases with increase in the hours he work. Teachers are responsible for everyday matters concerning their students, including making contact when appropriate with parents, dealing with pastoral matters, and dealing with students. During the interview with the Principals and the TSC County, it was revealed that teachers were moderately stressed by the number of hours they attended to school activities. In this respect, one Principal stated: Teachers work from 7.00am to $4.00 \mathrm{pm}$ and sometimes extend to $6.00 \mathrm{pm}$. This stresses them because they don't have time to attend to their personal issues. They are sometimes forced to carry some work home and this leads to disagreements with the family members. It was further revealed from open ended question that teachers annual leave that should be taken only when teachers are on holidays was stressing teachers as most of them wished to take the leave when students were on session. In other sector, employees were paid for the leave days but in teaching, teachers were not paid.

Many teachers are forced to pursue a masters degree in degree causes that are offered over the weekends and school based because they are not given an opportunity to go for regular causes, this is enough to stress a teacher. From the open ended questions, it was revealed that teachers were not happy with the current study leave policy, most teachers wished to further their studies but the Government had not given them the opportunity. It was also revealed that the study leave was to be granted after serving the Government for five years, unfortunately it was not automatic. It was further revealed that those who wished to further their PHD degrees were only to be given study leave without pay and this was really stressing teachers who wished to study. On average, employment factors had a moderate influence on stress among teachers in public secondary schools in Kakamega North sub-county. This means that these factors do affect teachers' performance and so measures have to take to minimize their effects.

Employment factors of the teachers stress level could be accounted for by other factors. These included clocking in and clocking out of the school, attending of academic days on Saturday and imprest policy as was indicated by qualitative data from open ended items in the questionnaire and interview findings. In this respect, one principal stated: Teachers complain so much when academic days are scheduled on Saturday. Teachers feel that Saturday is their relaxation day and so many do not attend such meetings that lead to confrontation between teachers and the administration.

Four out of 25 had a low influence on stress among teachers in Kakamega North sub-county. These were: career development opportunities, teachers dressing code, sick leave policy and maternity leave policy. Eleven factors out of 25 had high influence on stress among teachers in public secondary schools in Kakamega North subcounty. These were: teachers' job groups, teachers' promotion policy, teachers' house allowance, teachers' medical allowance, teachers' commuter allowance, Government decision on teachers' strikes, retirement policy, workload, deployment policy and five year employment policy. One factor out of 25 had very high influence on stress among teachers in public secondary schools in Kakamega North sub-county. This is study leave policy. Teachers apply for study leave but the majority is not granted the leave. On average, employment factors had a moderate influence on stress among teachers in public secondary schools in Kakamega North sub-county. Employment factors are a significant predictor of stress among teachers in Kakamega North sub-county. Employment factors accounts for $118 \%$ of the stress among teachers. They also have a moderate influence on stress among teachers.

\section{CONCLUSIONS}

Employment factors had a weak positive influence on teachers' stress levels. However the influence was significant. This means that one unit increase in employment factors would increase stress among teachers by a number of units. The stress among teachers overly was below the borderline. That is, it was not critical and therefore not worrisome. The level of stress among teachers revealed by descriptive statistics, which was moderate was due to other factors, notwithstanding the influence of employment factors. The findings of this study continued the findings that indicated that many teachers serving in government or public schools experience high stress levels. 


\section{RECOMMENDATIONS}

Since the teachers' views on stress are negative, the following measures may be considered in alleviation of tress.

i) Industrial disputes involving national strikes should be dealt with strictly in accordance with the legislations governing labour disputes.

ii) Wage bill for teachers should be regularly reviewed and collective Bargaining agreements adhered to by invoking proactive approach.

iii) The workload for teachers should be smart by taking into account the auxiliary services provided by teachers such as guidance and counselling, co-curricular activities, research conflict resolution and community service.

iv) Government policies pertaining to education such as hardship allowance, medical allowance leave, staffing, promotion, deployment and transfer should be reviewed regularly with a view to improving the teaching profession.

\section{REFERENCES}

Abirami, V. (2012). Levels of stress among college teachers with reference to Coimbatore district, Research world Journal of Arts, Science \& Commerce Vol. III, Issue4(2): 93-104.

Adeniyi, S. O,.Fakolade, O., Aremum, F. O. \&Adeyinka, T. (2010). Perceived Causes of Job Stress Among Special Educators in Selected Special and Integrated Schools in Nigeria.New Horizons in Education, Vol.58 (2): $72-82$.

Aftab, M. \&Khatoon, T. (nd). Demographic differences and occupational stress of secondary school teachers European Scientific Journal March edition Vol. 8(5): 159-179.

Aikman, S. \&Unterhalter, E. (2005). Beyond access: Transforming policy and practicefor gender equality in education. London: Oxford.

Alam, M. T.\&Farid, S. (2011). Factors Affecting Teachers Motivation.International Journal of Business and Social Science Vol. 2 (1): $298-304$.

Alemu Y., Teshome, A., Kebede, M. \&Regassa, T. (2014). Experience of stress among student-teachers enrolled in postgraduate diploma in teaching: The case of Haramaya University cluster centers, Ethiopia. African Educational Research Journal Vol. 2(3): 96-10.

Anbu, A. (2015). Professional Stress of Higher Secondary School teachers. International Journal of Multidisciplinary research and Development.2(1):1-3.

Antoniou, A., Ploumpi, A. \&Ntalla, M. (2013), Occupational stress and professional burnout in teachers of primary and secondary education: The role of coping strategies psychology 2013. Vol.4, No.3A: 349-355.

Antoniou, Polychroni, and Vlachakis, (2006). Gender and Age differences in Occupational Stress and Professional burnout between Primary and Secondary School teachers in Greece. Journal of Managerial Psychology 21(7): $682-690$

Anwar, K., Ishak, M. S., Sadaf, K,Shafiq, G. (2012). Teachers' Stress, Performance \& Resources: The Moderating Effects of Resources on Stress \& Performance.International Review of Social Sciences and Humanities Vol. 2 (2): 21-29 www.irssh.com.

Areekkuzhiyil (2014). Factors Influencing the Original Stress among teachers working in Higher Education sector in Keraha; An Empirical analysis. Journal Research and Pedagogic Interventions 2(2):1-15.

Arul, A. A. (2011). Study on causes and coping strategies for stress among college teachers with special reference to Coimbatore region. Indian Streams Research Journal Vol. - I, issue.

Ayoti, C. \& Poipoi, M.W. (201I). Factors contributing to stress among public secondary school teachers in Vihiga district, Kenya. International Journal of Current Research Vol. 33, (4):190-193.

Barbara, B. (2011). Teachers Remuneration and performance of schools under Uganda Primary Education system in Uganda.A case study of Wakiso District. A research Report submitted in partial fulfillment of the requirement of Bachelor of Commerce of Makerere University.

Beckley, J. (2011). The wellbeing of New Zealand teachers: The relationship between health, stress, job demands and teachers efficacy Thesis Masey University, Albany.

Bibi, S., Yasmin, B., Fozia, B. \& Mola, D. S. (2012). The Nature and Impact of Teacher Stress in the Private Schools of Gilgit-Baltistan, Pakistan. International Journal of Academic Research in Progressive Education and Development Vol. 1, (20: 64-84.

Boyland, L. (2011). Job stress and coping strategies of elementary principals: A statewide study. Current Issues in Education, 14 (3):1-11 Retrieved from http://cie.asu.edu/ojs/index.php/cieatasu/article/view/806.

Bratton, J. \& Gold, J. (1999). Human resource management, theory and practice, second edition, Polgrave New York. Chris Kyriacou, C. \&Chien, P. (2004). Teacher stress in Taiwanese primary schools. 
Commer, P. J., Hanif, R., Tariq, S. \&Nadeem, M. (2011). Personal and Job Related Predictors of Teacher Stress and Job Performance among School Teachers Soc. Vol. 5 (2): 319-329.

Curtaz, D. M. (1997). Perceived causes of stress and burnout as reported by elementary teachers at an urban school thesis submitted in partial fulfillment of the requirements for the degree of masters of arts in education (educational leadership) at California state university, sacramento fall.

Darmody, M. \&Emer Smyth, S. (2001). Job Satisfaction and Occupational Stress among Primary School Teachers and School Principals in Ireland.A Report Compiled by the ESRI on Behalf of The Teaching Council. The Economic and Social Research Institute Whitaker Square Sir John Rogerson's Quay Dublin 2.

Decenzo, D. A. \& Robbins, S. P. (2006).Personnel Human Resource Management.New Delhi. Prentice Hall

Dessler, G. (2008). Human resource management, $11^{\text {th }}$ edition New Delhi India.

Dunyilemi, B.O. (1992). Source and Social Correlates of occupational stress among Nigerian primary school teachers. www.researchgate.net.

Eres, F. \&Atanasoska, T. (2011). Occupational Stress of Teachers: A Comparative Study Between Turkey and Macedonia International Journal of Humanities and Social Science Vol. 1 No. 7: 59-65. Journal of Educational Research and Essays Vol. 1(1): 1- 4 Jan. 2013.

Fisher, M.H. (2011). Factors Influencing Stress, Burnout, and Retention of Secondary Teachers.Current Issues in Education, 14(1). Retrieved from http://cie.asu.edu/

Fraenkel, J. R. \&Wallen, E.N. (2009). How to Design and Evaluate Research in Education, New York: McGraw-Hill Companies.

Gebrekirstos, H.A. (2015). Occupational Stress among Secondary School Teachers and their Strategies. The case of Central zone of Tigray Region, Ethiopia.International Journal of Academic Research In Education and Reviews 3(6):143-157

Govindarajan, K. A. (2012). Study on the Level of Stress And Coping Strategies among Primary Teachers In Tamilnadu. International Multidisciplinary: 19-25.

Haastrup, T., Ekundayo, H.T. \&Kolawole, A. O. (2013). Stress among Secondary School Teachers in Ekiti State, Nigeria. Journal of Educational and Social Research Vol. 3 (2) pp 311 Doi:10.5901/jesr.2013.v3n2p311 -315

Hadi, A. A., Naing, N. N., Daud, A., Nordin, R. \&Sulong, M.R. (2009). Prevalence and factors associated with stress among secondary school teachers in Kota Bharu, Kelantan, Malaysia Vol. 40 (6):1359-1370.

Hasty, R.E. (2007). Teacher attrition: the relationship between teachers' stress and their intentions to leave their current positions. A Dissertation Presented in Partial Fulfillment of the Requirements for the Degree of Doctor of Educational Leadership. University of Phoenix.

Holeyannavar, P.G. \& ITAGI, S.K. (2010). Stress and health status of primary school teachers Karnataka J. Agric. Sci., 23 (4) : 620-624.

Howard, S., \& Johnson, B. (2004). Resilient teachers: resisting stress and burnout. Social Psychology of Education , 7: $399-420$.

Igharo, K. O. (2013, March). Stress: effects on school leadership and its management. International Researcher Vol. 2 (1): 104-115

Inyanji, J. \&Cherotich, J. (2014). Standard Newspaper Friday, June 2014.

Jaiyebo, A. O. \& Jibril, M.A. (2008). Sources of Occupational Stress among Secondary School Administrators in Kano State, An International Multidisciplinary Journal, Ethiopia Vol. 2 (3): 116-129.

Karihe, Namusonge and Iravo (2015). Work facilities as a determinant of occupational stress and employee performance. International Journal of Science and Research4(5)1925-1930.

Kayastha, D.P. \&Kayastha, R. (2012). A study of occupational stress on job satisfaction among teachers with particular reference to corporate, higher secondary school of Nepal: Empirical study, NEPAL.

Kazi, S.S., Shah, I. M., \& Khan, A.(2013) . Occupational Stress, Performance and Emotional Intelligence: A Critical Review International Review of Social Sciences and Humanities Vol. 5, No. 1: 185-191 www.irssh.com,

Kendi, R.S. (2012). Impact of occupational stress on head teachers' tasks in secondary schools of Kisumu county, Kenya. A research project submitted for the degree of master of education in the school of educational management, policy and curriculum studies of Kenyatta University, Kenya.

Kerr, R.A., Breen, J., Delaney, M., Kelly, C. \&Miller, K(2011). "A Qualitative Study of Workplace Stress and Coping in Secondary Teachers in Ireland," Irish Journal of Applied Social Studies: Vol. 11: Issue. 1, Article 3. Available at: http://arrow.dit.ie/ijass/vol11/iss1/3 pg 1-38.

Khan, A., Shah, I.M., Khan, S., \&Gul, S. (2012). Teachers' Stress, Performance \& Resources. The Moderating Effects of Resources on Stress and Performance: Review of Social Sciences and Humanities Vol. 2, (2): 21-29.

Kithokoo, M. A. (2008). School factors affecting performance in Kenya certificate of primary education in public primary schools in Yatta Division lower Yatta District, Kitui County. A Research Project, Kenyatta University.

Klassen, R., M., Usher, E.L. \& Bong, M. (2010). 'Teachers' Collective Efficacy, Job Satisfaction, and Job Stress in Cross-Cultural Context', The Journal of Experimental Education, 78: (4): 464- 486. 
Klassen, R.M. \& Chiu, M.M. (2010). Effects on Teachers' Self-Efficacy and Job Satisfaction: Teacher Gender, Years of Experience, and Job Stress. Journal of Educational Psychology American Psychological Association Vol. 102, No. 3: 741-756.

Koech, S. J., Tikoko, B. J., Bernard, Chemwei, B. (2014). Institutional factors that influence teacher turnover in public secondary schools in Baringo District.

Kumar and Deo (2011). Stress and Worklifeof college teachers. Journal of the Indian Academy of Applied Psychology.37 Special Issue 78-85

Kwaku, N.E. (2012). Occupational stress and its effects on job performance: A case of Koforidua Polytechnic. Unpublished Masters of Business Administration.Kwame Nkrumah University of Science and Technology.

Kyriacou, C. \&Chien, P. (2004) Teacher stress in Taiwanese primary schools. Journal of Educational Enquiry, Vol. 5 (2): $86-104$.

Manjula, C. (2007). A Study on Personality Factors Causing Stress among School Teachers M.Phil. Dissertation, submitted in partial fulfillment of the requirement for the M. Phil degree in Psychology to Mother Teresa Women's University, Kodaikanal.

Maphalala, M.C. (2014). The Manifestation of Occupational Stress in the Teaching Profession: The Unheeded Voices of Teachers Mediterranean. Journal of Social Sciences MCSER Publishing, Rome-Italy Vol. 5 (10): 7788.

Mondal, J., Shrestha, S. \&Bhaila, A. (2011). School Teachers: Job Stress and Job Satisfaction, Kaski, Nepal. International Journal of Occupational Safety and Health, Vol. 1: 1-7 http://nepjol.info/index.php/IJOSH.

Musyoka, M., Ogutu, M., \&Awino, Z. B. (2012). Employee Stress and Performance of Companies Listed in the Nairobi Securities Exchange. DBA Africa Management Review 2012, Vol. 3 (1):115-129.

Naidoo, K. Botha, C. J. \&Bisschoff, C. A.(2013). Causes of Stress in Public Schools and its Impact on Work Performance of Educators Journal of Science, 34(2): 177-190.

Ncube, A. C. \&Tshabalala, T. (2013). Impact on Performance of Teachers InNkayi District, Nova. Journal of Medical and Biological Sciences Vol. 1(1):15-23.

Ngari, S.M., Ndungu, A., Mwonya, R., Ngumi, O., Mumiukha, C., Chepchieng, M. \&Kariuki, M. (2013).Levels of stress among secondary school administrators and its implication in education management in Kenya.Academic Journals.

Ngeno, G. (2007). Causes of Burnout among Primary school teachers within Kericho Municipality, Kenya.Journal of Technology and Education in Nigeria 12(2): 9-18.

Okeke, C.I.O. \&Dlamin, C. C. (2013). An empirical study of stressors that impinge on teachers in secondary schools in Swaziland South African Journal of Education; 33(1): 1-12.

OlaitanO.L., Oyerinde, Obiyemi, O. \&Kayode, O.O. (2010).Prevalence of Job Stress among Primary School Teachers in South-west, Nigeria. African Journal of Microbiology Research March 42010 Vol. 4 (5): 1-9.

Olayiwola, S. (2008). Dimensions of Job Stress among Public Secondary school principals. Thesis, ObafemiAwolowo University, Ile-Ife, Nigeria.

Olivier, M.A.J. (2003). The extent and causes of stress in teachers in the George region South African Journal of Education EASA Vol. 23(3): 186 - 192

Oriwa, A. T. (2010). Beneficiary's involvement in constituency development fund financed projects, a case of Nyando constituency, Kenya. Unpublished Master Thesis, University of Nairobi.

Oso, Y.W. \&Onen, D. (2005). Writing Research Proposal Report. Kisumu: Options printers and publishers.

Ozturk, G. (2011). Public Primary School Teachers' Perceptions of their Working Conditions and Job Stress Cases from Istanbul and Stockholm.Institute of International Education Report 121 Institute of International Education Stockholm, Sweden.

Peltzer, K., Shisana, O., Zuma, K., Wyk, B.V. \&Zungu-Dirwayi, N. (2008). Job stress, job satisfaction and stressrelated illnesses among South African educators, Stress and Health Wiley Inter Science.

Professional Dialogue. (2012). Stress in the Workplace: Causes, Effects \& How to Cope Vol. 8, No. 1, www.acepcape.ca.

Putter, L. (2003). Stress factors among teachers in schools of industry thesis, university of Zululand.

Reddy, G. L. \&Anuradha, R. V. (2013). Occupational Stress of Higher Secondary Teachers Working in Vellore District. International Journal of Educational Planning \& Administration. ISSN 2249-3093 Vol. 3(1): 9-24 (C) Research India Publications.

Republic of Kenya (2007). Labour Laws 2007. Nairobi Government Printer.

Republic of Kenya (2010). The Constitution of Kenya 2010.Nairobi Government Printer.

Republic of Kenya (2012). Teachers Service Commission Act, 2012. Nairobi Government Printer.

Republic of Kenya (2013). The Basic Education Act, 2013.Nairobi Government Printer.

Rintaugu, E. G. (2013).Socio-Demographic Factors and Causes of Job Stress of Sports Personnel in Kenyan Universities. Human Resource Management Research (4): 166-172. 
Salahudin, S.N., Abdullah, M.M., Hitam, S.B.(nd). Personal Characteristics, Occupational Stress and Turnover Intentions Among School Teachers in Negeri Sembilan, Malaysia. http://www.pdfcomplete.com

Santiago, M.J., Otero-López, J.M, Castro, C.\&Villardefrancos, E. (2008). Occupational stress in secondary school teachers: Examining the role of students' disruptive behaviour and/or attitudes and the perceived difficulty in conflict management. European Journal of Education and Psychology 2008, Vol. 1, (1): 39-50.

Senthil, K. A., Mohan, S., \&Velmurugan, R. (2013). Causes of work stress of teachers in engineering education Asian journal of management research 406 Vol. 3 (2): 406-419.

Skaalvik, E. M. \&Skaalvik, S. (2015). Job Satisfaction, Stress and Coping Strategies in the Teaching ProfessionInternational Education Studies; Vol. 8, (3): 181-192.

Shernoff , E.S., Mehta, T. G., Atkins, M. S., Torf , R. \& Spencer, J. (2011). A Qualitative Study of the Sources and Impact of Stress among Urban Teachers School.Mental Health (2011) 3:59-69.

Sichambo, M.N., Maragia, S.N., \&Simiyu, A.M.(2012). Causes of Burnout among Secondary School Teachers: A Case of Bungoma North District-Kenya. International Journal of Academic Research in Progressive Education and Development Vol. 1 (4): 195-2002.

Siddiqui, F. A. (2012). Occupational stress in teachers: a comparative study of public and private schools in Hyderabad city. Journal of Education Vol.42 Issue 13:62-73.

Sprenger, J. (2011). Stress and Coping Behaviors among Primary School Teachers. A Thesis Presented To the Faculty of the Department of Health Education and Promotion East Carolina University in Partial Fulfillment of the Requirements for the Degree Master of Arts.

Steyn, G. M. \&Kamper, G. D. (2006). Understanding occupational stress among educators: an overview Africa Education, Vol. 3(1): 13-1.

Subbulaxmi, S. (2002). Productivity and stress Vol 3: 26-28.

Sulaiman, F.R. \&Akinsanya, P.O. (2014). Stress and instructors' efficiency in Ogun State Universities: Implications for Nigerian educational policy. African Journal of Guidance and Counseling Vol. 1 (1): 001-00.

Sultana, B., Bano, Y.B., Bano, F. \&Shafa, M.D. (2012). The Nature and Impact of Teacher Stress in the Private Schools of Gilgit-Baltistan, Pakistan.International Journal of Academic Research in Progressive Education and Development ,1(2):64-84.

Syed, G. A., Alain, R. \& Muhammad, A. A.(2012). Impact of organizational role stressors on faculty stress \& burnout (An exploratory analysis of a public sector university of Pakistan).

Tahir Q. (2011). Effectiveness of Teaching Stress on Academic Performance of College Teachers in Pakistan. International Journal of Humanities and Social Science Vol. 1 (3): 123-129

Tashi, K. (2014). Occupational Stress among Bhutanese Teachers Asian Journal of Management Sciences \& Education Vol. 3(2): 71-79 www.ajmse. leena-luna.co.jp.

Tasleema, J., Muddasir, H. M., \&Javied, A. (2013). A study of social and family role stress among primary school teachers of district Budgam, j\&k, india. Journal of Educational Research and Essays Vol. 1(1): 1- 4 Jan.

Teachers Service Commission (2005).Code of Regulations for Teachers.Teachers Service Commission. Nairobi: Teachers Service Commission.

TJjpti, S., Avantika, S. Prabha, S. (2007). Relationship of Stress and Job Satisfaction: A Comparative Study of Male \& Female of Dual Career Teacher Couples of India working paper No.263.

Torres, R.M., Lawver, R.G. \& Lambert, D.M. (2009). Job-related stress among secondary agricultural education teachers: A comparison study: Journal of Agricultural Education Vol. 50(3): $100-111$.

Tsai, E., Fung, L.K.\& Chow, B.C. (2006). Sources and Manifestations of Stress in Female Kindergarten Teachers International Education Journal, 7(3): 364-370.

Tsigilis, N. (2011). Burnout among physical education teachers in primary and secondary schools. International Journal of Humanities and Social Science Vol. 1 (7): 53-5.

Tuck, B., Eleanor, H., Manthei, R., Adair, V.Adair\& Moore, D. (1999). Sources of occupational stress in New Zealand primary teachers AARE-NZARE Melbourne, Australia.

Usman, Akbar, Ramzan (2013). Effect of Salary and Stress on Job satisfaction of teachers in District Sialkot, Pakistan. Journal of Humanities and Social Sciences. 15(2):68-74.

Vipinder, N. \&Sarita, A. (2013).Occupational stress and health among teacher educators. International Journal of Advanced Research in Management and Social Sciences Vol. 2 ( 8): 1-13.

Wangai, M. M. (2012). Factors affecting job satisfaction among secondary school teachers of Mwatate district, Kenya. Project paper presented as a partial fulfillment for the requirement of the award of certificate in senior management course, Gtiembu, Kenya.

Yambo, J.M.O., Kindiki, J.N. \&Tuitoek, J.K.F. (2012).Investigating High School Principals' Stress in Relation to their Job Experience in Schools in Southern Nyanza Region of Kenya. International Journal of Academic Research in Progressive Education and Development, Vol. 1, (4): 44-63. 
Younghusband, L.J. (2005). High School Teachers' Perceptions of Their Working Environment in Newfoundland: Unpublished PhD thesis School of Graduate Studies

Yusoff, R.B.M., Kha,. A. \&Azam, K. (2013). Job Stress, Performance and Emotional Intelligence in Academia. Journal of Basic and Applied Scientific Research J. Basic. Appl. Sci. Res., 3(6):1-8.

Zedan, R. \&Bitar, J. (2012).Stress and coping strategies among science elementary school teachers in Israel. Universal Journal of Education and General Studies Vol. 2(3): 084-097.

Santavirta N, Solovieva, S. \& Theorell, T. (2007). The association between job strain and emotional exhaustion in a cohort of 1028 Finnish teachers. British Journal of Educational Psychology, 77:213-228.

Cite this Article: Baraza OT and Simatwa EMW (2016). Influence of Employment Factors on Stress among Public Secondary School Teachers in Kenya. A Case Study of Kakamega North Sub-county. Greener Journal of Educational Research, 6(3): 091-114, http://doi.org/10.15580/GJER.2016.3.051616087 